\title{
DRUG-USE DYNAMICS, TREATMENT NEED AND AVAILABILITY OF TREATMENT FACILITY: EVIDENCE FROM SELECTED BUNKS IN UYO METROPOLIS IN NIGERIA
} UZ̈YWANIE NARKOTYKÓW, POTRZEBA LECZENIA
I DOSTEPPNOŚĆ PLACÓWEK LECZNICTWA:
BADANIA WYBRANYCH MELIN W METROPOLII
UYO W NIGERII

\author{
Gboyega E. Abikoye ${ }^{1,2} \mathbb{D}$, Elizabeth A. Okonkwo ${ }^{1}$, Isidore S. Obot ${ }^{2}$ \\ ${ }^{1}$ Department of Psychology, University of Uyo, Uyo, Nigeria \\ ${ }^{2}$ Center for Research and Information on Substance Abuse, Uyo, Nigeria
}

Alcohol Drug Addict 2021; 34 (2): 119-130 DOI: https://doi.org/10.5114/ain.2021.109543

\begin{abstract}
Introduction: Although it has not been empirically documented, bunk patrons are commonly perceived to engage in excessive and hazardous drug use. This study investigated drug use, treatment needs and availability of treatment facilities among patrons of bunks in Uyo.

Material and methods: The snowball technique was used to recruit 189 patrons from three bunks in the Uyo metropolis. Data were collected by the researchers and research assistants using a structured questionnaire consisting of widely-used measures of drug use, treatment needs and availability of facilities. Participant mean age was 26.54 years of age.
\end{abstract}

\begin{abstract}
Streszczenie
Wprowadzenie: Niniejsze badanie dotyczyło używania narkotyków przez osoby korzystające z melin (bunks) w Uyo, potrzeb leczenia i dostępności placówek medycznych. Bywalcy melin - choć nie zostało to potwierdzone empirycznie - są powszechnie postrzegani jako osoby, które nadmiernie i ryzykownie używają narkotyków.

Materiał i metody: Rekrutację 189 klientów trzech melin w metropolii Uyo przeprowadzono metodą kuli śniegowej. Badacze i ich asystenci zebrali dane za pomocą ustrukturyzowanego kwestionariusza składającego się z powszechnie stosowanych narzędzi mierzących używanie narkotyków, potrzeby lecznicze i dostępność placówek medycznych.
\end{abstract}

Correspondence to/Adres do korespondencji: Gboyega E. Abikoye, Department of Psychology, University of Uyo, Nwaniba Road, Uyo, P.M.B. 1017, Uyo, Akwa Ibom State, Nigeria, phone: +2348055065741, e-mail: ageabikoye@yahoo.com, gboyegaabikoye@uniuyo.edu.ng

Authors' contribution/Wkład pracy autorów: Study design/Koncepcja badania: G.E. Abikoye, I.S. Obot; Data collection/Zebranie danych: G.E. Abikoye, E.A. Okonkwo; Statistical analysis/Analiza statystyczna: G.E. Abikoye, I.S. Obot; Data interpretation/Interpretacja danych: G.E. Abikoye, E.A. Okonkwo, I.S. Obot; Acceptance of final manuscript version/Akceptacja ostatecznej wersji pracy: G.E. Abikoye; Literature search/Przygotowanie literatury: G.E. Abikoye, E.A. Okonkwo, I.S. Obot

No ghostwriting and guest authorship declared./Nie występują zjawiska ghostwriting i guest authorship.

Submitted/Otrzymano: 16.08.2020 • Accepted/Przyjęto do druku: 21.01.2021

(c) 2021 Institute of Psychiatry and Neurology. Production and hosting by Termedia sp. z o.o.

This is an open access article under the CC BY-NC-ND license (http://creativecommons.org/licenses/by-nc-nd/4.0/) 
Results: A mean DUDIT (Drug Use Disorders Identification Test) score of 32.72 and a treatment need score of 11.05 was obtained. While $83.6 \%$ of respondents were polydrug users, $64.02 \%$ had injected drugs, $42.86 \%$ had used cocaine and $38.10 \%$ had psychiatric co-morbidity. Although 52\% were motivated for treatment, only $11 \%$ were currently in counselling. There was a positive association detected between drug use and treatment needs $(r=0.32, p<0.01)$. Male gender is associated with more drug use $(r=-0.47, p<0.01)$ and fewer treatment needs $(r=0.28, p<0.05)$. Years of patronage is positively related to drug use and treatment needs.

Discussion: The findings were consistent with commonly-held perceptions regarding excessive and hazardous drug use in the bunks. This could be attributed to the availability of these drugs in an atmosphere devoid of apprehension about arrest by law enforcement agents.

Conclusions: We emphasised the need to provide affordable, accessible and evidence-based treatment as well as extending the healthcare system to include drug-use problems.

Keywords: Drug addiction, Bunk patrons, Treatment needs, Facilities, Uyo.
Średnia wieku uczestników badania wynosiła 26,54 roku.

Wyniki: Średni wynik DUDIT (Testu Identyfikacji Zaburzeń Związanych z Używaniem Narkotyków) wyniósł 32,72 , a potrzeby leczenia - 11,05. Większość respondentów $(83,6 \%)$ używała różnego rodzaju narkotyków, 64,02\% - narkotyków w iniekcjach, 42,86\% - kokainy, a u 38,10\% używanie narkotyków współwystępowało $\mathrm{z}$ zaburzeniami psychicznymi. Chociaż 52\% osób było zmotywowanych do leczenia, tylko $11 \%$ korzystało z pomocy. Stwierdzono dodatni związek między używaniem narkotyków a potrzebą leczenia $(r=0,32, p<0,01)$. Mężczyźni używali więcej narkotyków $(r=-0,47, p<0,01)$ i mieli mniejszą potrzebę leczenia $(r=0,28, p<0,05)$ niż kobiety. Liczba lat korzystania $\mathrm{z}$ melin była pozytywnie związana $\mathrm{z}$ używaniem narkotyków i potrzebą leczenia.

Omówienie: Wyniki były zgodne z powszechnym przekonaniem dotyczącym nadmiernego i ryzykownego używania narkotyków przez bywalców melin. Można to przypisać dostępności tych narkotyków w atmosferze pozbawionej obaw o aresztowanie.

Wnioski: Wyniki badania wskazują na potrzebę zapewnienia niedrogiego, dostępnego i opartego na dowodach leczenia, a także potrzebę umiejscowienia problemów związanych z używaniem narkotyków w systemie opieki zdrowotnej.

Słowa kluczowe: uzależnienie od narkotyków, klienci melin, potrzeby leczenia, placówki medyczne, Uyo.

\section{- INTRODUCTION}

Drug addiction is a major public health concern for most countries, especially in developing world where resources needed to mitigate the various deleterious impacts of drug abuse and addiction are limited [1]. Widespread use of different types of psychoactive drugs among different populations has been reported [2-5] among about 275 million people worldwide, with roughly $5.6 \%$ of the global population of 15-64 years of age using drugs at least once in 2016 [1]. The report further suggests that, globally, 13.8 million young people of 15-16 years of age used cannabis in the past year, which is equivalent to a rate of $5.6 \%$. A recent national survey of the United Nations Office on Drugs and Crime (UNODC) found that an estimated $14.4 \%$ of the Nigerian population or 14.3 million people of 15-64 years of age had used drugs, apart from alcohol and tobacco, in 2017 [6]. In addition, 10.6 million people had used cannabis in the past 12 months, 4.6 million opioids (mainly tramadol, and to a lesser extent morphine), 2.4 million cough syrups (containing codeine or dextromethorphan), 481,000 tranquillisers, 340,000 ecstasy and 300,000 had used solvents/inhalants [6]. Furthermore, 1 of 5 of all drug users were injecting drug users, 1 in every 5 was dependent, 1 in every 3 users used cannabis, 1 in every 5 used opioids, 1 in every 7 used amphetamines and 1 in every 4 drug user was female [6].

Various health-related, social and economic problems associated with drug use are well documented [7-15]. Some of the 31 million drug users 
suffer from drug use disorders [1]. Drug use has been shown to be a leading cause of violence and is a major cause of premature deaths [16]. In Nigeria, involvement of the youth in various antisocial activities, such as cultism, kidnapping, armed robbery and prostitution is often attributed to the influence of psychoactive substances [1]. Members of hidden or hard-to-reach populations have been shown to engage in a host of health-compromising behaviours like injecting drug use [14] and unprotected sex [17].

There is a huge and growing body of empirical literature on drug use in the general population, students and other easily accessible populations $[2,4,5,10]$. It has been observed, however, that empirical evidence is scanty as regards our understanding of the dynamics of drug-use problems in hidden, hard-to-reach populations [18]. Although some researchers have reported higher and more hazardous patterns of drug use among hard-toreach populations like injection drug users [14], law enforcement officers [18], transport workers [19] and commercial sex workers [17], there is no previous empirical documentation of drug use and treatment needs among bunk patrons.

However, in a study by Bah [20] to determine the risk and prevalence of drug abuse among street children (focusing on those in or around car parks), findings revealed a high level of drug abuse despite a reasonably high level of awareness of its negative impacts. Among this group, cannabis was the most commonly abused drug although use of cocaine, hashish and heroin was also reported [20]. Despite reported availability of treatment facility, participants were mostly reluctant to utilise the facilities due to fear of social stigmatisation, exclusion and discrimination and mistreatment by staff [20]. In one of the few available empirical investigation of drug use among hard-to-reach populations, Abdulmalik et al. [21] found high drug use and other forms of high risk behaviour among the Almajiris in northern Nigeria (Almajiri is a term used to describe children in northern Nigeria who are meant to learn the Qur'an and receive religious instructions, but mostly end up roaming the streets to beg and participate in other undesirable behaviours). According to Abdulmalik et al. [21], the prevalence of drug use among the Almajiris was $66.2 \%$ and the most frequently used drugs were stimulants $(49.7 \%)$, volatile solvents $(21.5 \%)$, cigarettes (19.1\%) and cannabis (18.5\%).

\section{Drug treatment and control in Nigeria}

In Nigeria, services are provided for people with drug-use problems by government-owned (tertiary) health facilities and some non-governmental organisations (NGOs). These facilities are mostly located in the state capitals, which implies that all potential service users that are not resident within the capital city (even some within the city, depending on residential location) would need to travel for several hours to get to the treatment facilities. The few available treatment facilities and inadequate personnel mean that waiting time would be unnecessarily extended since people congregate on the few available facilities from all over the state or even beyond. A number of NGO facilities, operating fee-based, residential treatment models (although some operate non-residential, out-patient services) also exist $[22,23]$. The financial implications of accessing these privately-owned NGO treatment centres are beyond the reach of most potential service users so there is a huge gap as regards meeting drug-use disorder treatment needs. The national survey of the UNODC in Nigeria identified other barriers to treatment to include high cost of treatment, unavailability of suitable treatment and perceived stigma [6]. Another barrier to service utilisation, also traceable to inadequate facilities, is lack of awareness and/or insufficient information regarding drug treatment facilities [17, 24].

Drug use is largely perceived from a criminological perspective in Nigeria. The approach to drug control in Nigeria is supply suppression rather than demand reduction; the focus is on preventing or reducing illicit drugs in circulation, rather than discouraging individuals from getting involved in illicit drug use and offering affordable treatment to people that are already hooked. Consistent with this approach, possession of an illicit substance is a criminal offence and it is punishable by imprisonment of various durations [25, 26]. Drug users are routinely arrested, prosecuted and incarcerated. This approach, instead of curbing illicit drug use and trafficking, has engendered a networks of powerful and highly organised drug syndicates that have not only ensured availability of all types of psychoactive drugs but have also devised ingenious means of dealing with interference of law enforcement agents [27]. Obviously, this drug-control approach constitutes a huge barrier 
to treatment utilisation as potential service users fear arrest $[15,17,28]$.

The 2015 World Drug Report highlights a global shortage of treatment centres and limited resources for drug addiction rehabilitation [29]. Globally, it is estimated that approximately one in six problem drug users accesses treatment each year [30]. However, there are huge regional disparities, with approximately one in eighteen problem drug users receiving treatment in Africa, compared to one in five receiving treatment in Western and Central Europe, one in four in Oceania and one in three in North America [31]. Health professionals in Nigeria have described drug addiction treatment as inadequate, expensive and hard to access, while users have commonly complained of unsuccessful attempts to overcome their addiction either because treatment facilities are not available or not accessible [15]. Unfortunately, these concerns have neither been sufficiently documented not properly addressed. Given the myriad of physical, psychological, social and economic sequalae of drug use and addiction, there is need for more evidence-based efforts aimed at mitigating the problem because, as pointed out by O'Neil [32], the cost of leaving drug users untreated is often much higher than that of providing access to treatment.

Studies on treatment need and availability of facilities for people with drug use/addiction problems in Nigeria are very scant. Researchers have reported that factors such as perceived discrimination and stigma, high cost of service, centralised facility, referral practices and help-seeking preferences are crucial to utilisation and effectiveness of mental health services [33-35]. However, Abikoye [15] in a qualitative study of selected service users in Bayelsa State, Nigeria, found that perceived high costs of service, accessibility and its associated costs, unavailability of specialised centres and facilities to manage substance use disorders, manpower shortage occasioning unnecessarily long waiting time, attitudinal problems, cultural issues resulting in relapse, perceived stigma, shame and discrimination were factors responsible for service users' apathy toward seeking help for drug-related problems. The centralised system of healthcare in most parts of Nigeria could also be a reason for perception of unavailability of facilities. For instance, there is no government psychiatric hospital in Uyo, and the only facility for treatment of drug addiction is the Psychiatric Department of the University of Uyo Teaching Hospital. Although there are few drop-in centres (DICs) in the city and a counselling unit in the National Drug Law Enforcement Agency (NDLEA), these are non-residential and only provide counselling services.

Bunk patrons represent a special group of drug users. Bunks are hostel-like facilities, established by drug barons in many urban centres in Nigeria. Apart from the ease of obtaining drugs, patrons need not worry about interference of law enforcement agents as there seems to be some implicit understanding between bunk owners and law enforcement officer. The bunks seem to enjoy 'immunity' from arrest as patrons are hardly arrested. The bunk, is therefore, seen as not just a safe haven for obtaining and using drugs of all kinds, it also provides an atmosphere of acceptance, common experience and normality without fear of stigmatisation. In fact, many patrons sleep in the bunks because they feel safe and more accepted there. Given this scenario and despite the social dynamics of life in the bunk being as yet not fully understood, drug use in the bunks is generally considered to be more excessive and more dangerous compared to that beyond the bunks. A comprehensive understanding of the problem from the perspectives of bunk patrons as well as their motivation to access treatment and availability of these treatment facilities can help shape a more robust policy and evidence-based future research direction.

There is a need, therefore, for an empirical investigation of drug use dynamics, treatment needs and availability of treatment facility of this hardto-reach but high-risk drug-user group. Considering the large number of bunks scattered across $\mathrm{Ni}$ gerian urban centres and the wide patronage that the bunks seem to be enjoying, findings of the study would be useful to key stakeholders in driving evidence-based interventions. Findings of the study should also be useful for the policy makers on possible ways of dealing with drug abuse and treatment needs among drug users, especially those with elevated risk for drug addiction. Additionally, findings of the study should enrich the body of scientific literature on the subject matter. This study, therefore, aims to explore drug use among patrons of selected bunks in Uyo. The study is also aimed at investigating participants' treatment needs and availability of treatment facility. 


\section{- MATERIAL AND METHOdS}

\section{Setting and participants}

One hundred and eighty-nine (189) respondents selected from three bunks located within Uyo metropolis participated in this descriptive cross-sectional survey using the snowball technique. Uyo, the capital of Akwa Ibom State, is located in the south of Nigeria. Uyo is a rapidly developing city with an estimated population of 1,143,689 people [36]. The three bunks are located within the metropolis and each has an average of 90 patrons. Participants' mean age was $26.54(\mathrm{SD}=5.81)$. In terms of gender, $135(71.4 \%)$ of participants were males while $54(28.6 \%)$ were females. With regards to marital status, $142(75.1 \%)$ were single, 27 (14.3\%) were married, $11(5.8 \%)$ were separated and $8(4.2 \%)$ were divorced. One third of participants $(64,33.9 \%)$ had completed high school, $58(30.7 \%)$ had a national diploma, 56 $(29.6 \%)$ had a bachelor degree or its equivalent, 6 (3.1\%) had postgraduate qualifications while only 1 respondent $(0.5 \%)$ had no formal education.

\section{Measures}

Relevant data were collected using a structured questionnaire. Background information on age, gender, education and duration of patronage were collected in the first section of the questionnaire.

Drug use was assessed using the Drug Use Disorders Identification Test (DUDIT) [37] which consists of 11 items. Items 1-9 are scored 0, 1, 2, 3 and 4 ; while items $10-11$ are scored 0,2 and 4 . The minimum scorable points on DUDIT is 0 and maximum score is 44 . When the DUDIT is used in a group where one does not expect to find many drug users, a cut-off point of 6 or more for men with drug-related problems and a cut-off point of 2 or more for women are stipulated [37]. Considerable evidence supports the psychometric adequacy of DUDIT $[18,37]$. In the present study, a high internal consistency ( $\alpha$ 0.93) was obtained for DUDIT.

Treatment need of participants was measured by adapting the 20 -item Vermont Treatment Needs Questionnaire (VTNQ) [38]. The questionnaire is indicated for assessing treatment needs of individuals with drug-use problems. According to the manual of the scale, levels of treatment need are categorised depending on scores obtained as follows: 0 - 5 indicates low treatment needs, 6-10 indicates moderate treatment needs, 11-15 indicates high treatment needs and 16 and above indicates urgent treatment needs. An additional one item adapted from the UNODC Drug Users Questionnaire [2] assessing the current extent of treatment need for drug use problem was also employed. The treatment need was categorised into 3: 'urgent need', 'some need' and 'no need'.

Availability of treatment facility was assessed using the adapted version of UNODC Drug Users Questionnaire [2] comprising of 8 structured statement of the availability of different drug treatment and rehabilitation services in the respondent's area. The types of facilities include private hospital/clinic, psychiatric hospital, other governmental hospitals, NGO/treatment centre, home-based treatment, faith-based treatment centre, NDLEA counselling centre and traditional medical centre. Participants are required to respond on a 3-point forced-choice format: 'yes', 'no' or 'don't know'

\section{Procedure}

Purposive sampling technique was used to select three of the five bunks identified in Uyo metropolis. After obtaining permission from the bunk owners, data was personally collected through the snowball technique. A patron (focal person) was initially identified in each bunk and after necessary rapports have been established, the focal person completed the questionnaire and then invited others to be interviewed. The chain process went on simultaneously in the three bunks for two weeks after which saturation was deemed to have been reasonably attained. At the end of the two-week period, 207 copies of questionnaire were administered across the three bunks out of which 189 were returned with usable data representing a $91.30 \%$ response rate. Participation in the study was voluntary and all participants signed a consent form. Participants were informed that they were at liberty to opt out of the interview or not answer any question if they so chose. Confidentiality and anonymity were also guaranteed. Each participant received refreshments and a toilet soap upon completion of the questionnaire. The study protocol was approved by the Research Ethics Review Committee of the Ministry of Health, Akwa Ibom State, Nigeria.

\section{- Results}

\section{Drug use}

Results showed that mean score on DUDIT was $32.72(\mathrm{SD}=10.55)$. This is considerably higher 
Table I. Participant's responses Drug Use Disorder Identification Test (DUDIT) items

\begin{tabular}{|c|c|c|}
\hline DUDIT Items/Responses & $n$ & $\%$ \\
\hline \multicolumn{3}{|c|}{ How often do you use drugs other than alcohol? } \\
\hline Never & 16 & 8.5 \\
\hline Once a month or less & 58 & 30.7 \\
\hline 2-4 times a month & 33 & 17.5 \\
\hline 2-3 times a week & 35 & 18.5 \\
\hline 4 times a week/more & 47 & 24.9 \\
\hline
\end{tabular}

Do you use more than 1 type of drug on the same occasion?

\begin{tabular}{l|l|l}
\hline Never & 31 & 16.4 \\
\hline Once a month or less & 46 & 24.3 \\
\hline 2-4 times a month & 51 & 27.0 \\
\hline 2-3 times a week & 28 & 14.8 \\
\hline 4 times a week/more & 33 & 17.5
\end{tabular}

How many times do you take drugs on a typical day when you use drugs?

\begin{tabular}{l|c|c}
\hline 0 times & 14 & 7.4 \\
\hline $1-2$ times & 64 & 33.9 \\
\hline 3-4 times & 51 & 27.0 \\
\hline $5-6$ times & 28 & 14.8 \\
\hline 7 or more times & 32 & 16.9
\end{tabular}

How often are you influenced heavily by drugs?

\begin{tabular}{l|l|l}
\hline Never & 25 & 13.2 \\
\hline Less than once a month & 41 & 21.7 \\
\hline Every month & 46 & 24.3 \\
\hline Every week & 35 & 18.5 \\
\hline Daily/almost every day & 42 & 22.2 \\
\hline
\end{tabular}

Over the past year, have you felt that your longing for drugs was so strong that you could not resist it?

\begin{tabular}{l|l|l}
\hline Never & 23 & 12.2 \\
\hline Less than once a month & 31 & 16.4 \\
\hline Every month & 45 & 23.8 \\
\hline Every week & 51 & 27.0 \\
\hline Daily/almost every day & 39 & 20.6 \\
\hline
\end{tabular}

Has it happened, over the past year, have you felt that you have not been able to stop taking drugs once you started?

\begin{tabular}{l|l|l|}
\hline Never & 23 & 12.2 \\
\hline Less than once a month & 33 & 17.5 \\
\hline Every month & 38 & 20.1 \\
\hline Every week & 40 & 21.2 \\
\hline Daily/almost every day & 55 & 29.1 \\
\hline
\end{tabular}

Table I. Cont.

\begin{tabular}{|l|c|c|}
\hline DUDIT Items/Responses & $n$ & $\%$ \\
\hline $\begin{array}{l}\text { How often over the past year have you taken drugs } \\
\text { and then neglected to do something you should have } \\
\text { done? }\end{array}$ \\
\begin{tabular}{l|c|c|}
\hline Never & 24 & 12.7 \\
\hline Less than once a month & 33 & 17.5 \\
\hline Every month & 45 & 23.8 \\
\hline Every week & 34 & 18.0 \\
\hline Daily/almost every day & 53 & 28.0 \\
\hline
\end{tabular}
\end{tabular}

How often over the past year have you needed to take a drug the morning after heavy drug use the day before?

\begin{tabular}{l|c|c|}
\hline Never & 24 & 12.7 \\
\hline Less than once a month & 40 & 21.2 \\
\hline Every month & 32 & 16.9 \\
\hline Every week & 49 & 25.9 \\
\hline Daily/almost every day & 44 & 23.3 \\
\hline
\end{tabular}

How often over the past year have you had guilt feelings or a bad conscience because you used drugs?

\begin{tabular}{l|l|l}
\hline Never & 40 & 21.2 \\
\hline Less than once a month & 30 & 15.9 \\
\hline Every month & 40 & 21.2 \\
\hline Every week & 27 & 14.3 \\
\hline Daily/almost every day & 52 & 27.5
\end{tabular}

Have you or anyone else been hurt (mentally or physically) because you used drugs?

\begin{tabular}{l|l|l}
\hline No & 70 & 37.0 \\
\hline Yes, but not over the past year & 71 & 37.6 \\
\hline Yes, over the past year & 48 & 25.4
\end{tabular}

Has a relative or a friend, a doctor or a nurse, or anyone else, been worried about your drug use or said to you that you should stop using drugs?

\begin{tabular}{l|l|l}
\hline No & 36 & 19.0 \\
\hline Yes, but not over the past year & 75 & 39.7 \\
\hline Yes, over the past year & 78 & 41.3
\end{tabular}

than the expected average score of 6 and 2 for males and females respectively in normal populations. Results also showed that while $8.5 \%$ of respondents never used drugs other than alcohol, $30.7 \%$ had used drugs other than alcohol, 17.5\% had used drugs between $2-4$ times in a month, $18.5 \%$ between 2-3 times a week and $24.9 \%$ at least 4 times a week. Results also indicated that $83.6 \%$ of respondents were polydrug users. Number of times that used drugs on a typical day varied from none (7.4\%), 1-2 times (33.9\%), 3-4 times (27.0\%), 5-6 
times $(14.8 \%)$ to 7 or more times $(16.9 \%)$. These and other results, including influence of drug use, craving for drugs, how drug use has affected other activities, guilt feelings as a result of drug use, harm to others resulting from drug use, as well as concerns by significant others about drug use, are presented in Table I.

\section{Extents of treatment needs}

We used the Vermont's Treatment Needs Questionnaire (VTNQ) to explore the extent of treatment needs among participants. A mean treatment need score of 11.05 obtained for participants in the present study indicated, according to the VTNQ norms, a need for professional treatment. Results in percent are presented in Table II. The majority of participants (64.02\%) had used drugs intravenously. Only $1.59 \%$ had ever been on medication-assisted treatment and none had been successful, $42.86 \%$ had used cocaine, $38.10 \%$ had psychiatric co-morbidity and, interestingly, almost $52 \%$ were motivated for treatment although only about $11 \%$ were currently going for counselling.

\section{Availability of drug abuse/addiction treatment facilities}

Furthermore, we explored availability of treatment facilities around the residential areas of participants. Using the UNODC (2018) template, eight possible drug abuse/addiction treatment facilities were identified. Results are presented in Table III.

Results presented in Table III showed that most facilities were not available/accessible to majority of the respondents. While less than $5 \%$ reported availability of psychiatric hospital, less than $1 \%$ for NGO treatment centre, about $18 \%$ for other government hospitals and $31.69 \%$ for private hospitals/clinics. Availability was $0 \%, 13.23 \%, 4.23 \%$ and $13.23 \%$ for home-based treatment, faith-based treatment centre, NDLEA counselling centre and traditional medical centre respectively.

We performed a series of bivariate analyses in order to understand the relationships among variables in the study. Results of the bivariate analyses showed a positive association between drug use and treatment needs $(r=0.32, p<0.01)$. Male gender is associated with more drug use $(r=-0.47$, $p<0.01)$ and having less treatment needs $(r=0.28$, $p<0.05)$. Years of patronage is positively related to drug use $(r=0.41, p<0.01)$ and treatment needs
Table II. Participants' responses to Vermont Treatment Needs Questionnaire items

\begin{tabular}{|c|c|c|}
\hline Items indicative of treatment needs & Yes (\%) & No (\%) \\
\hline $\begin{array}{l}\text { Have you ever used a drug } \\
\text { intravenously? }\end{array}$ & $\begin{array}{c}121 \\
(64.02)\end{array}$ & $\begin{array}{c}68 \\
(35.98)\end{array}$ \\
\hline $\begin{array}{l}\text { If you have ever been on } \\
\text { medication-assisted treatment } \\
\text { (e.g. methadone, buprenorphine) } \\
\text { before? }\end{array}$ & $\begin{array}{c}3 \\
(1.59)\end{array}$ & $\begin{array}{c}186 \\
(98.41)\end{array}$ \\
\hline $\begin{array}{l}\text { If yes, were you successful? (If } \\
\text { never in treatment before, leave } \\
\text { answer blank.) }\end{array}$ & 0 & $\begin{array}{c}3 \\
(100)\end{array}$ \\
\hline $\begin{array}{l}\text { Do you have a chronic pain issue } \\
\text { that needs treatment? }\end{array}$ & $\begin{array}{c}66 \\
(34.92)\end{array}$ & $\begin{array}{c}123 \\
(65.08)\end{array}$ \\
\hline $\begin{array}{l}\text { Do you have any significant } \\
\text { medical problems (e.g. hepatitis, } \\
\text { HIV, diabetes)? }\end{array}$ & $\begin{array}{c}37 \\
(19.58)\end{array}$ & $\begin{array}{c}152 \\
(80.42)\end{array}$ \\
\hline $\begin{array}{l}\text { Do you ever use cocaine even } \\
\text { occasionally? }\end{array}$ & $\begin{array}{c}81 \\
(42.86) \\
\end{array}$ & $\begin{array}{c}108 \\
(57.14)\end{array}$ \\
\hline $\begin{array}{l}\text { Do you ever use benzodiazepines, } \\
\text { even occasionally? }\end{array}$ & $\begin{array}{c}121 \\
(64.02)\end{array}$ & $\begin{array}{c}68 \\
(35.98)\end{array}$ \\
\hline Do you have problem with alcohol? & $\begin{array}{c}24 \\
(12.70)\end{array}$ & $\begin{array}{c}165 \\
(87.30)\end{array}$ \\
\hline $\begin{array}{l}\text { Do you have any psychiatric } \\
\text { problems? }\end{array}$ & $\begin{array}{c}72 \\
(38.10) \\
\end{array}$ & $\begin{array}{c}117 \\
(61.90) \\
\end{array}$ \\
\hline $\begin{array}{l}\text { Are you currently going for any } \\
\text { counseling? }\end{array}$ & $\begin{array}{c}21 \\
(11.11)\end{array}$ & $\begin{array}{c}168 \\
(88.88)\end{array}$ \\
\hline Are you motivated for treatment? & $\begin{array}{c}98 \\
(51.85)\end{array}$ & $\begin{array}{c}91 \\
(48.15)\end{array}$ \\
\hline $\begin{array}{l}\text { Do you have a partner that uses } \\
\text { drugs or alcohol? }\end{array}$ & $\begin{array}{c}62 \\
(32.80) \\
\end{array}$ & $\begin{array}{c}127 \\
(67.20) \\
\end{array}$ \\
\hline $\begin{array}{l}\text { Do you have } 2 \text { or more close } \\
\text { friends or family members who do } \\
\text { not use alcohol or drugs? }\end{array}$ & $\begin{array}{c}157 \\
(83.07)\end{array}$ & $\begin{array}{c}32 \\
(16.93)\end{array}$ \\
\hline Is your housing stable? & $\begin{array}{c}71 \\
(37.57) \\
\end{array}$ & $\begin{array}{c}118 \\
(62.43)\end{array}$ \\
\hline $\begin{array}{l}\text { Do you have access to reliable } \\
\text { transportation? }\end{array}$ & $\begin{array}{c}85 \\
(44.97) \\
\end{array}$ & $\begin{array}{c}104 \\
(55.03)\end{array}$ \\
\hline $\begin{array}{l}\text { Do you have a reliable phone } \\
\text { number? }\end{array}$ & $\begin{array}{c}179 \\
(94.71)\end{array}$ & $\begin{array}{c}10 \\
(5.29)\end{array}$ \\
\hline $\begin{array}{l}\text { Did you receive a high school } \\
\text { diploma or equivalent (e.g. did you } \\
\text { complete }>12 \text { years of education)? }\end{array}$ & $\begin{array}{c}184 \\
(97.35)\end{array}$ & $\begin{array}{c}5 \\
(2.65)\end{array}$ \\
\hline Are you employed? & $\begin{array}{c}39 \\
(20.63)\end{array}$ & $\begin{array}{c}150 \\
(79.37)\end{array}$ \\
\hline $\begin{array}{l}\text { Do you have any legal issues } \\
\text { (e.g. charges pending, probation/ } \\
\text { parole)? }\end{array}$ & $\begin{array}{c}7 \\
(03.70)\end{array}$ & $\begin{array}{c}182 \\
(96.30)\end{array}$ \\
\hline Are you currently on probation? & 0 & $\begin{array}{c}189 \\
(100)\end{array}$ \\
\hline $\begin{array}{l}\text { Have you ever been charged (not } \\
\text { necessarily convicted) with drug } \\
\text { dealing? }\end{array}$ & $\begin{array}{c}78 \\
(41.27)\end{array}$ & $\begin{array}{c}111 \\
(58.73)\end{array}$ \\
\hline
\end{tabular}


Table III. Availability of drug treatment and rehabilitation services in your area

\begin{tabular}{|l|l|c|c|c|}
\hline S/N & Type of facility & Yes (\%) & No (\%) & Don't know (\%) \\
\hline 1 & Private hospital/clinic & $58(30.69)$ & $131(69.31)$ & 0 \\
\hline 2 & Psychiatric hospital & $9(4.76)$ & $180(95.24)$ & 0 \\
\hline 3 & Other Government Hospitals & $34(17.99)$ & $155(82.01)$ & 0 \\
\hline 4 & Non-governmental organization (NGO) Treatment Centre & $1(0.53)$ & $188(99.47)$ & 0 \\
\hline 5 & Home-based treatment & 0 & $189(100.00)$ & 0 \\
\hline 6 & Faith Based Treatment Centre & $25(13.23)$ & $161(85.19)$ & $3(1.59)$ \\
\hline 7 & $\begin{array}{l}\text { National Drug Law Enforcement Agency (NDLEA) } \\
\text { Counselling Centre }\end{array}$ & $8(4.23)$ & $149(78.84)$ & $32(16.93)$ \\
\hline 8 & Traditional Medical Centre & $25(13.23)$ & $109(57.67)$ & $55(29.10)$ \\
\hline
\end{tabular}

Table IV. Bivariate analysis of relationships among age, sex, years of patronage, drug use and perceived treatment needs

\begin{tabular}{|l|c|c|c|c|c|c|c|}
\hline Variable & Age & Sex & Years of patronage & Drug use & Treatment needs & Mean & SD \\
\hline Age & - & & & & & 26.53 & 5.81 \\
\hline Sex & 0.012 & - & & & & - & - \\
\hline Years of patronage & $0.28^{\star}$ & -0.14 & - & & & 5.65 & 2.11 \\
\hline Drug use & $-0.27^{\star}$ & $-0.47^{\star \star}$ & $0.41^{\star *}$ & - & & 32.72 & 10.55 \\
\hline Treatment needs & $0.29^{\star}$ & $0.28^{\star}$ & $0.35^{\star \star}$ & $0.32^{\star \star}$ & - & 11.05 & 2.52 \\
\hline
\end{tabular}

${ }^{+}$Coding for Sex: male $=1$, female $=2$

${ }^{*}$ Correlation significant at 0.05 level

${ }^{\star *}$ Correlation significant at 0.01 level

$(r=0.35, p<0.01)$. These and other relationships are presented in Table IV.

\section{- Discussion}

This study was aimed at assessing the dynamics of drug use, treatment need and perceived availability of treatment facility among patrons of bunks in Uyo, Nigeria. Respondents revealed very high levels and hazardous patterns of drug use. We also found that majority of respondents were polydrug users. Although we found no prior empirical data on drug use among patrons of bunks in Nigeria, findings of the present study in these regards are consistent with results of studies in other hard-to-reach populations $[17,22,26]$. Findings of the present study also appear to lend credence to commonly-held perceptions regarding excessive and hazardous drug use in the bunks, a finding that could be attributed to availability of these drugs in an atmosphere devoid of apprehension about arrest by law enforcement agents.

Our findings on high levels of treatment needs and low rates of treatment uptake are consistent with similar findings based on other drug users group $[15,17,22]$. These findings, though not unexpected (given what is commonly "known" about bunks as a different world, where patrons engage in reckless drug use), imply serious public health implications considering that almost half of the respondents had used cocaine and many respondents were injecting drug users: cocaine use is associated with poorer treatment outcome $[35,38]$ while injecting drug use is associated with higher severity of disease and predicts the need for longterm treatment $[35,38]$.

Findings of the study also indicated that respondents were almost unanimous in their perception that treatment facilities for addiction treatment are not available. Although no previous study had examined availability of treatment facility specifically from the perspectives of bunk patrons, huge shortages of treatment facilities for mental disorders generally [33, 34], and drug addiction problems in particular $[15,22,23,34$, 35], have been reported. Even where such facilities exist, they are mostly concentrated in the capital cities [15] thereby making accessibility very difficult. Non-utilisation of the available treatment facilities in Nigeria by people with drug use problems is, therefore, not due to lack of motivation for service uptake but rather because of a number 
of barriers including fear of arrest, inadequate and urbanised system in which people need to travel long distances to the facility, extended waiting times, high costs of treatment, shame and stigma $[2,15,17,27,28]$.

\section{- CONCLUSIONS}

We conclude that drug use is not just high among bunk patrons, use also indicates hazardous patterns as reflected in high reporting of polysubstance use, injection, types and frequency of drugs commonly used, experience of craving, social and other life domain disruptions and compulsive use as well as harm to self and others. Majority of bunk patrons are willing to access treatment. Although most respondents had never being in treatment before, they are willing to enrol into a treatment facility if such is made available and affordable (free). Most respondents seem oblivious of available and affordable treatment services.

The strength of this study lies in its novelty and the public health implications of its findings. To our knowledge, no previous study had empirically documented drug use, treatment needs and perceived availability of facilities among patrons of bunks in Nigeria. However, like other non-experimental studies, this research may be susceptible to desirability bias, faking and human tendencies. The exploratory, cross-sectional nature of the study means that it is impossible to infer causation. Nevertheless, having put in place necessary quality control measures, these potential limitations are not strong enough to compromise the study findings and conclusions. Research on drug use among hard-to-reach populations is very scant in Nigeria. The relative dearth of empirical investigation into drug use and other high risk behaviours of these groups mean that undertaking evidence-based interventions is made practically difficult, if not impossible.

\section{- IMPLICATIONS AND RECOMMENDATION}

Given the high level and hazardous patterns of drug use among bunk patrons as well as the danger that these portend for this group of people, their family and the society, it is imperative to consider the treatment needs of high risk groups such as bunk patrons a matter of urgent public health concern. The high level of reported need for treatment by respondents in the present study makes provision of accessible and affordable treatment a matter of great public health importance. Treatment facilities should be made available and should not be concentrated in the cities or urban areas only. This would make such facilities easier and cheaper to access by potential users that are resident in rural and semi-urban areas. Because people with drug-related problems are usually ambivalent about treatment initiation and possible outcomes, easy access to available services the moment potential users are ready for treatment is critical. When the few available service centres are found mostly in the tertiary health hospitals (many are considered inaccessible in terms of distance and perceived cumbersomeness of procedure as at present in most Nigerian settings) the picture can be discouraging. Potential service users, such as members of the population under consideration and other hard-to-reach populations, may be lost if treatment is not immediately available or readily accessible. As with other chronic conditions, the earlier treatment is offered in the management of drug addiction, the greater the likelihood of positive outcomes. One way of achieving this is by establishing community treatment facilities that can easily be accessed at a subsidised fee.

Currently, drug use problem is largely situated in the criminal justice system in Nigeria. Individuals with a drug use problem are routinely arrested and incarcerated instead of being assisted to access treatment. This has resulted in drug users getting smarter in evading arrests while the drug control issues become more compounded. As obtained in other areas, mainstreaming or domiciling drug use problem in the healthcare system rather than in the criminal justice system has the potentials of making treatment more accessible as well as helping to normalise drug abuse treatment by reducing stigma, fear and discrimination that are commonly associated with drug abuse treatment in settings where drug use is criminalised. Therefore it is recommended that the drug use problem should be considered a health-related problem and mainstreamed in the healthcare system so that problematic users can easily access treatment. Fortunately, major stakeholders in drug control in Nigeria, including the NDLEA, are coming to the realisation that the emphasis on criminalising users and supply suppression has not been effective in 
drug control. Therefore focus should be shifted to demand reduction.

The relative dearth of empirical investigation into the drug use behaviour of bunk patrons makes it dif- ficult to understand the issues holistically and precludes evidence-based interventions. The need for more empirical investigation into drug use and other aspects of life in the bunk cannot be overemphasised.

\section{Conflict of interest/Konflikt interesów}

None declared./Nie występuje.

Financial support/Finansowanie

None declared./Nie zadeklarowano.

\section{Ethics/Etyka}

The work described in this article has been carried out in accordance with the Code of Ethics of the World Medical Association (Declaration of Helsinki) on medical research involving human subjects, Uniform Requirements for manuscripts submitted to biomedical journals and the ethical principles defined in the Farmington Consensus of 1997.

Treści przedstawione w pracy są zgodne z zasadami Deklaracji Helsińskiej odnoszącymi się do badań z udziałem ludzi, ujednoliconymi wymaganiami dla czasopism biomedycznych oraz z zasadami etycznymi określonymi w Porozumieniu z Farmington w 1997 roku.

\section{References/Piśmiennictwo}

1. United Nations Office on Drugs and Crime. World Drug Report 2018. United Nations publication, Sales No. E.18.XI.9. Vienna: UNODC; 2018.

2. Atilola O, Ola B, Abiri G. Service and policy implication of substance use disorders among adolescents in juvenile correctional facilities in Lagos, Nigeria. Global Mental Health 2016; 3 (e30). DOI: https://doi.org/10.1017/gmh.2016.25.

3. Dumbili EW. Cannabis normalization among young adults in a Nigerian city. $J$ Drug Issues 2020; 50(3): 286-302. DOI: https://doi.org/10.1177/0022042620912805.

4. Gureje O, Degenhardt L, Olley B, Uwakwe R, Udofia O, Wakil A, et al. A descriptive epidemiology of substance use and substance use disorders in Nigeria during the early 21st century. Drug Alcohol Dep 2007; 91(1): 1-9. DOI: 10.1016/j.drugalcdep.2007.04.010.

5. Mehanović E, Virk HK, Akanidomo I, Pwajok J, Prichard G, van der Kreeft P, et al. Correlates of cannabis and other illicit drugs use among secondary school adolescents in Nigeria. Drug Alcohol Dep 2020; 206, 107457. DOI: https://doi.org/10.1016/j.drugalcdep.2019.04.028.

6. United Nations Office on Drugs and Crime. Drug Use in Nigeria. Vienna: UNODC; 2018.

7. Patton ON. Behaviour health. A Handbook of Health Enhancement. New York: Cambridge University Press; 1998.

8. Abayomi O, Ojo TM, Ibrahim N, Adelufosi AO, Obasan A. Prevalence and correlates of substance use among persons with mental disorders in a Nigerian psychiatric hospital. Afr J Drug Alcohol Stud 2012; 11(1): 29-35.

9. Abiona TC, Aloba OO, Fatoye FO. Patterns of alcohol consumption among commercial road transport workers in a semi-urban community in South Western Nigeria. East Afr Med J 2006; 83(9): 494-9.

10. Abikoye GE, Adekoya JA. Predicting Substance Abuse in a Sample of Nigerian Undergraduate Students: The Role of Core Self-Evaluations and Delay of Gratification. Psychol Stud 2010; 55(4): 299-307.

11. Hawkins JD, Catalano RF, Miller JY. Risk and protective factors for alcohol and other drug problems in adolescence and early adulthood: implications for substance abuse prevention. Psychol Bull 1992; 12: 64-105. 
12. Santi S, Best J, Brown KS. Social environment and smoking initiation. Int J Addict 1990; 25: 881-903.

13. Seeman M, Seeman TE. Health behavior and personal autonomy. A longitudinal study of the sense of control in illness. J Health Soc Behav 1983; 24: 144-60.

14. Nelson E, Abikoye GE. Syringe Sharing and the Risk of Viral Transmission among People who Inject Drugs in Nigeria: Structural, Relational and Subjective Influences on Behaviors. J Drug Issues 2019; 49(2): 387-404.

15. Abikoye GE. Factors affecting the management of substance use disorders: Evidence from selected service users in Bayelsa State. Afr J Drug Alcohol Stud 2015; 14(2): 115-23.

16. Agrawal RK, Puliyel JM, Chansoria M, Mukerejee M, Kaul KK. Comparative study of the personality correlates and the nature of drug abuse in schools and colleges. Indian J Pediatr 2007; 49(5): 76-85.

17. Nelson E, Abikoye GE. Multiple Barriers to Utilization of Drug Abuse Treatment by Female Street Sex Workers in Nigeria. J Psychoactive Drugs 2019; 51(4): 383-90.

18. Abikoye GE, Awopetu RG. Drug Use and Multidimensional Work Performance in a Sample of Policemen in Akwa Ibom State. Afr J Drug Alcohol Stud 2017; 16(2): 59-68.

19. Abikoye GE, Sholarin MA, Ineme ME, Abikoye OE, Uso ME, Osinowo HO. Optimistic Bias, Perceived Social Norms and Cannabis Use among Road Transport Workers in Ibadan Metropolis. Int J Soc Sc 2017; 11(3): 83-96.

20. Abdulmalik J, Omigbodun O, Beida O, Adedokun B. Psychoactive substance use among children in informal religious schools (Almajiris) in northern Nigeria. Mental Health, Rel Cul 2009; 12(6): 527-42. DOI: 10.1080/13674670902832813.

21. Bah YM. Drug Abuse among Street Children. JClin Res HIV/AIDS Prev 2018; 3(3): 12-44. DOI: 10.14302/issn.2324-7339.jcrhap-18-2291.

22. Nelson EE, Dumbili EW, Odeigah OW. Drug use treatment during COVID-19 pandemic: community-based services in Nigeria, $J$ Subst Use 2020. DOI: https://doi.org/10.1080/ 14659891.2020.1838640.

23. Onifade PO, Somoye EB, Ogunwobi OO, Ogunwale A, Akinhanmi AO, Adamson TA. A descriptive survey of types, spread and characteristics of substance abuse treatment centres in Nigeria. Subst Abuse Treat Prev Policy 2011; 6(1): 25. DOI: https://doi.or$\mathrm{g} / 10.1186 / 1747-597 X-6-25$.

24. Ezenwa M, Orjiakor T, Ukwuma M, Oraetue H, Ude E, Nweze T. Tracking opiate routes in Nigeria: Identifying trafficking routes via dealers and users of tramadol and codeine. Bull Narc 2019; 62: 27-47. DOI: https://doi.org/10.17863/CAM.50293.

25. Obot IS. The Epidemiology of Tobacco and Alcohol Abuse in Nigeria. In: Obot IS (ed.). Epidemiology and Control of Substance Abuse in Nigeria. Jos: Centre for Research and Information on Substance Abuse (CRISA); 1993, p. 67-87.

26. Kalunta-Crumpton A (ed.). Pan-African Issues in Drugs and Drug Control: An International Perspective. Farnham, Surrey: Ashgate Publishing, Ltd.; 2015.

27. Abikoye GE, Edewor DO, Sunday DB, Abayomi O, Obot IS, Nelson EE. Socioeconomic Context of Cannabis Cultivation and Trafficking in Selected Nigerian Communities. Bull Narc 2019; 62: 9-26. DOI: https://doi.org/10.17863/CAM.50293.

28. Ebigbo PO, Elekwachi CL, Nweze CF. Challenges in the treatment of drug abuse in a Nigerian female health worker: a case study applying the Wawa technique. J Cont Psychother 2012; 42(4): 257-64. DOI: https://doi.org/10.1007/s10879-012-9213-9.

29. United Nations Office on Drugs and Crime. World Drug Report 2015. United Nations publication, Sales No. E.11.X.10. Vienna: UNODC; 2015.

30. Wang PS, Aguilar-Gaxiola S, Alonso J, Angermeyer MC. Use of mental health services for anxiety, mood, and substance disorders in 17 countries in the WHO World Mental Health Surveys. Lancet 2007; 370: 841-50.

31. United Nations Office on Drugs and Crime. World Drug Report 2011. United Nations publication, Sales No. E.11.X.10. Vienna: UNODC; 2011.

32. O'Neil SK. Demand side policies in the US war on drugs. Council on Foreign Relations blog, 6 September 2011, Demand Side Policies in the U.S. War on Drugs | Council on Foreign Relations (cfr.org) (Accessed: 18.07.2021). 
33. Gureje O, Alem A. Mental Health Policy Development in Africa. Bull World Health Org 2000; 78(4): 475-82.

34. Gureje O, Lasebikan VO, Ephraim-Oluwanuga O, Olley BO Kola L. Community study of knowledge of and attitude to mental illness in Nigeria. Br J Psychiatry 2005; 186: 43641.

35. Patel V, Araya R, Chatterjee S, Chisholm D, Cohen A, De Silva M, et al. Treatment and Prevention of Mental Disorders in Low-income and Middle-income Countries. Lancet 2007; 370(9591): 991-1005.

36. World Bank. Population Stat 2017-2020. Geneva: World Bank; 2020. https://populationstat.com/nigeria/uyo (Accessed: 14.08.2020).

37. Berman AH, Bergman H, Palmstierna T, Schlyter F. Drug Use Disorders Identification Test (DUDIT) Manual. Stockholm: Karolinska Institutet; 2003.

38. Brooklyn JR, Sigmon SC. Vermont Hub and Spoke Model Treatment Needs Questionnaire. Burlington, Vermont: University of Vermont; 2015. 